\title{
The Convergence of Subsects: Defining Where Deobandi and Salafi Subsects Intersect
}

Joshua Pease and James Hess

\begin{abstract}
The purpose of this qualitative research study is to compare the practical and philosophical limitations of moderate Deobandi and Salafi doctrine in contrast with their extremist brethren, specifically the Taliban and Salafi jihadists. This research followed a two-part methodology. The first part, meta-ethnography, as a form of meta-synthesis uses ethnographic accounts and qualitative studies as comparative values against each other. The second part of this method involved translating the highlighted variables of the four subjects into shared concepts. These methods were derived from historical connections to the source, the legitimacy of the party conducting the rationalization, and internal scholastic discourse. The subjects are united in their pursuit of their Islamism, and are distinguished through their origins and situational rationale. The subjects were found to have several similarities concerning their methods of interpreting sharia, but differ greatly in how that shari'a should be developed or implemented. The study concludes that the absence of unified Sunni leadership and scholastic enforcement has led to erratic evolutions of subsect ideologies about sharia and the idealized Islamist society. This study recommends that future research be conducted within a narrower scope, focusing on the political psychology of the subjects.
\end{abstract}

Keywords: Deobandi, Salafi, doctrine, Taliban, jihadists. shari’a, Sunni leadership, scholastic enforcement

\section{La Convergencia De Asignaturas: Definiendo Dónde Se Intercambian Los Subsectos Deobandi Y Salafi}

\section{RESUMEN}

El propósito de este estudio de investigación cualitativa es comparar las limitaciones prácticas y filosóficas de la doctrina moderada deobandi y salafista en contraste con sus hermanos extremistas, 
específicamente los yihadistas talibanes y salafistas. Esta investigación siguió una metodología de dos partes. La primera parte, la metaetnografía, como una forma de meta-síntesis, utiliza relatos etnográficos y estudios cualitativos como valores comparativos entre sí. La segunda parte de este método implicó traducir las variables destacadas de los cuatro sujetos en conceptos compartidos. Estos métodos se derivaron de conexiones históricas con la fuente, la legitimidad del partido que conducía la racionalización y el discurso escolástico interno. Los sujetos están unidos en la búsqueda de su islamismo y se distinguen por sus orígenes y su lógica situacional. Se encontró que los sujetos tenían varias similitudes con respecto a sus métodos de interpretación de la sharia, pero difieren mucho en cómo esa sharia debería ser desarrollada o implementada. El estudio concluye que la ausencia de un liderazgo sunita unificado y una aplicación escolástica ha dado lugar a evoluciones erráticas de las subsecciones de las ideologías sobre la sharia y la sociedad islamista idealizada. Este estudio recomienda que la investigación futura se lleve a cabo dentro de un ámbito más estrecho, centrándose en la psicología política de los sujetos.

Palabras clave: Deobandi, salafista, doctrina, talibanes, yihadistas. sharia, liderazgo sunita, cumplimiento escolar

\section{小派别的汇集：界定德奥班德教派 和萨拉菲教派之间的交叉}

摘要

本篇定性研究旨在比较与极端主义成员一尤其是塔利班和萨 拉菲圣战分子一形成鲜明对比的温和派德奥班德派教义和萨 拉菲派教义的实际限制和哲学限制。本研究的方法论由两部 分组成。第一部分是元民族志 (作为综合集成的一种形式) , 将民族志叙述和定性研究作为比较值。第二部分涉及将四 个主体的重点变量转化为共享概念。这些方法取自与来源相 关的历史联系、实行理性化 (rationalization) 的教派的合 法性、以及内部的宣讲话语（scholastic discourse）。各主 体通过各自对伊斯兰主义的追求而聚集在一起, 并通过各自 的起源和情境原则 (situational rationale) 而加以区分。 研究发现, 四个主体在诠释伊斯兰教法的方法上具有几个相 似点, 但在伊斯兰教法应如何发展和实施一事上存在巨大差 异。研究结论认为, 缺乏统一的逊尼派领导力和宣讲执行, 已导致关于伊斯兰教法和伊斯兰理想社会的小派意识形态出 


\section{现不稳定的发展。本研究建议, 未来研究应在更窄范围内进} 行，聚焦上述主体的政治心理学。

关键词: 德奥班德运动, 萨拉菲运动, 主义, 塔利班, 圣战 分子，伊斯兰教法（shari'a），逊尼派领导力，宣讲执行 (scholastic enforcement)

\section{Background}

\section{T}

The Deobandis and Salafis are scholastic Sunni sects rooted in their struggle to secure the ideal Islamist government. The Deobandis, borne from colonial struggles, were founded in 1866 at Deoband, India. ${ }^{1}$ From their university, Dar-Ulum-Deoband, the Deobandi mission sought to reestablish and elevate the role of the ulama in British-occupied India through a formalized academic atmosphere of higher learning, centered around the Islamic sciences of such things as the Hanafi fiqh, talid, and ijtihad. ${ }^{2}$ In comparison, the Salafis reject fiqh and seek to apply and practice the wisdom of the al-salaf al-salihin ("the pious predecessors," the first three generations of Muslims, including the
Prophet) through a variety of practices guided heavily by their ijtihad and taqlid amongst other doctrinal interpretations. $^{3}$ Contemporary Salafism, which debatably claims its heritage and identity from Muhammad ibn Abd al-Wahhab's revival in the middle of the eighteenth century, idealizes the Salaf as practicing the perfect form of sharia. ${ }^{4}$ Salafism is a methodology of practical Islam, and not a madhab (Sunni schools of fiqh and academic discipline) itself. ${ }^{5}$

Despite the range of differences between the Deobandi and Salafi ideologies, rhetoric, and practices, they share fundamental similarities in their pursuit to maintain Islamic purity and their idealized visions for an Islamic future. This alignment to the greater ends of Islam influenced how their means developed and were executed. What resulted

1 Ingram, Brannon D. Revival from below: The Deoband movement and global Islam. Oakland California: University of California Press, 2018. Kindle. 815.

2 Zaman, Muhammad Q. The ulama in contemporary Islam: Custodians of change. Princeton studies in Muslim politics. Princeton, N.J., Oxford: Princeton University Press, 2002. Kindle. 1036.

3 Kose, Sadi. ISIS: A Byproduct of Salafism? Translated by Adil al-Kalbani and Haatim al-Ouuni, 2017b. Kindle. 10.

4 Maher, Shiraz. Salafi-jihadism: The history of an idea. Oxford: Oxford University Press, 2016. Kindle. 06-08.

5 Duderija, Adis. "Mainstream Sunnism, Salafi-Jihadism and progressive Islam: Rejoinder to Alan Gabon's." Studies in Conflict \& Terrorism (2019): 1-12. https://doi.org/10.1080/1057610X.2019.1657297. 05. 
are two distinct groups with apparently diverging ideologies, rhetoric, and practices, but which have ultimately developed shared characteristics. This study will focus on the two progenitor sects, Deobandism and Salafism, and two of their politically extremist subsects, the Deobandi Taliban and the Salafi jihadists. If the primary subjects' beliefs and rhetoric can be enumerated in terms of their practices, then their distinct differences can be outlined and compared, and the groups may be differentiated from each other beyond political terms of moderation and extremism.

Research Question: What is the nature of the philosophical and practical similarities in shari'a and fiqh among some of the outstanding Deobandi and Salafi moderates and extremists?

\section{Definition of Terms}

Bid'a: Doctrinal "innovations or novelties that did not exist at the time of the Messenger of Allah." 6

Fiqh: Islamic jurisprudence as it relates to the four Sunni madhabs (not to be confused with usal al-fiqh, which relates to the principalities of Sunni jurisprudence sourced in the Quran and Sunna). ${ }^{7}$

Ijtihad: Legal term referring to the jurist's process of independent reasoning and rationalization to find a solution or opinion to a legal question within the terms of shari'a. ${ }^{8}$

Sharia: Uncodified, immutable Islamic law. ${ }^{9}$

Taqlid: The "layman who has not reached the stage of Ijtihad has to follow one of the four schools; because he/ she does not have the capability to read and comprehend all Islamic sources." ${ }^{10}$

\section{Purpose}

The purpose of this research study is to comparatively address the 1 similarities in the extremist ideologies and practices of the Deobandi Taliban and Salafi jihadists, versus their moderate origins in Deobandism and normative Salafism, respectively. This comparison is applied so that their common variables may be distilled and highlighted for further study, and used as future insight into the evolution of politico-religious extremism.

\section{REVIEW OF LITERATURE}

Whe literature used in this study
was sourced from Muslim
scholars, lay practitioners, and non-Muslim academics experienced in Islamic studies. Most of the sourc-

6 Kose, Sadi. Bid'ah: According to the Four Madhabs, 2017a. Kindle. 08.

7 Moj, Muhammad. The Deoband madrassah movement: Countercultural trends and tendencies. Diversity and plurality in South Asia. London: Anthem Press, 2015. 203-204.; Ingram (2018), 2768.

8 Maher, 66, 237.

9 Khan, Aamir I. The Dispute: Reconciliation between Shia, Sunni, and Salafi. Al Haqaiq Foundation, 2018. Kindle. 99; Moj, 221.

10 Khan, 12. 
es come from academic, scholarly, and other peer-reviewed sources. The research uses primary sources from relevant Muslim clerics when they could be found in English. There are several consistent themes throughout the literature, many of which are subservient to its attempts to describe the functional and ideological limitations of the moderate subsects in comparison to their extremist counterparts. ${ }^{11}$ This discourse highlights three central themes of discussion: the religious doctrine, its political application, and its practical application on general populations. These themes highlight significant gaps in objectivity.

\section{The Dar-Ulum-Deoband and the Deobandi Taliban}

\section{Beliefs}

The literature regarding the religious doctrine between the progenitor Deobandi school at Dar-Ulum-Deoband and the Taliban lacks traditional academic quality and quantity. The Deobandi ulama's (cadre of Islamic scholars) discussion is concerned with doctrinal subtlety and the continuity of their policies of non-innovation. ${ }^{12}$ There is some discourse that addresses the finite limits of innovation, but this discussion hardly rises to an academic level of organized discussion. External authors have organized some thematic trends in the religious evolution of Deobandism, as it relates to the Taliban, but these tend towards a historic retelling of events that do not address specific religious doctrine. ${ }^{13}$ Other, non-Deobandi, Sunni authors analyze the evolution of the Taliban in comparison to their moderate roots at the Dar-Ulum-Deoband. ${ }^{14}$ This is in keeping with the apologists' notion of both having to explain how the Taliban became extremists, and how the internal Deobandi ulama moderates both condemn and condone the Taliban's interpretations. ${ }^{15}$ The decentralization of Islamic studies ensures that, were progenitor Deobandi ulama interested in regulating other madrasas' commentary and curriculum, there would be no recourse to censure developing heresy or bid'a. ${ }^{16}$ There are few academic resources stemming from the Deobandi ulama, besides thousands of highly specific fatwas (legal opinion or ruling issued by an Islamic scholar) concerning appropriate individual behaviors within shari'a. ${ }^{17}$ The living state of the Deobandi Taliban's literature is more present in the political and practical aspects of sharia, than within an academic discussion of its religious doctrine.

11 Duderija (2019), 05.

12 Zaman, 645-652.

13 Syed, et al., 195.

14 Moj, 08-25.

15 Syed et al., 3087.

16 Arkoun, Mohammed. "Rethinking Islam Today." The Annals of the American Academy of Political and Social Science 588, no. 1 (2003): 18-39. https://doi.org/10.1177/0002716203588001003. 19.

17 Ingram (2018), 1182. 


\section{Rhetoric}

In contrast to the literature regarding doctrine, the body of literature surrounding the political development of Deobandism and the Taliban is rich with academic interest from both internal Muslim scholars and external, non-Muslim researchers. The academic quality of sources within this theme is substantially higher and within the bounds of traditional, Western standards of academics. The audience is more concerned with how the religion has secular governance as a fundamental facet of its existence and what those facets are, than of the nature of its politico-religious doctrine. The Deobandi scholars seek to provide a level of continuity to their doctrine, and the external researchers provide the progression of a moderate madrasa's development into political extremism. ${ }^{18}$ The breadth of the audience is also revealed in the quantity of sources discussing the politics of the Deobandi and Taliban subsects. The literature works within the theme that Deobandism and the Taliban are one and the same, but are different expressions from different people operating in different environments. This section of the literature works primarily in the subtleties of vocabulary as non-Muslim authors attempt to organize what defies organization. An example of this is the differences and extent of what is "Islam" versus what is "Islamism" or "jihad" versus "jihadism." These concepts both serve as religious identity and as religious purpose. ${ }^{19}$ There is not a significant representation of the ulama's interpretations in this regard.

\section{Actions}

The literature regarding the applied doctrine reflects the greatest divergence between the Deobandi ulama and the Taliban. The divergence implicates the separation between the moderates and the extremists as an attempt to explain why the moderates are different from the extremists in the great majority of cases. ${ }^{20}$ The literature around the Taliban's practices in such activities as religion, Islamism, and warfare unintentionally places them in the spotlight of what makes them extremist versus moderate. ${ }^{21}$ Non-Muslim scholars are quick to point out the tribal origins for the Taliban's practices, and that they are not necessary halal (permissible) in the traditional terms of Sunni Islam, or of Deobandism. ${ }^{22}$ Beyond this oft recurring observation, the literature exists in a state of comparison between Taliban practices that are not condoned by the majority of Sunni Islam and how these

18 Zaman, 977-1003.

19 Amin, Husnul. "Mainstream Islamism without Fear: The Cases of Jamaat-e-Islami and Jamiat Ulemae-Islam in Pakistan.” Romanian Journal of Political Science 14, no. 2 (2014): 126-57. 127.

20 Metcalf, Barbara D. 'Traditionalist' Islamic activism: Deoband, Tablighis, and Talibs. ISIM papers 4. Leiden: ISIM, 2002.

21 White, J. T. "Understanding the Taliban: Assessing Religious Categories of Analysis." Religion and Violence (2012).

22 Metcalf, 15-17. 
practices are categorically different from moderate Sunnism. The literature attempts to define the limits of terrorism and warfare within the Taliban's behaviors.

\section{Salafi Quietists \& Jihadists}

\section{Beliefs}

The early post-9/11 years show an elementary understanding of Salafism as a branch of Islam that is, by its nature and creed, following extremist ideologies and practices. As the years progressed, the literature evolved a better understanding of the separated natures of the three primary Salafist branches. ${ }^{23}$ The demonstrations and activities from the different branches brought stark contrasts among their followers. The studies eventually brought out the subtle qualities and diffused structures from this time and highlight the branches as almost completely individual beliefs within Islam. ${ }^{24}$ While a clearly defined element of the literature from the earliest studies of Salafism, there is a period in the literature that looks at political Salafism as a rift within the quietists and the jihadists. ${ }^{25}$ Some authors look at this development as a rationalized evolution for a religious group attempting to implement their version of government. ${ }^{26}$. Others look at the reformation of political Salafism as the inevitable progression of extremists who faced the frontlines of implementing Salafism through jihad, and realized the futility of their endeavor through applied force. ${ }^{27}$ There is not much literature dedicated to the core beliefs of the political Salafists, except to state where they sit between the quietists and the jihadists. The Salafi jihadists have the largest body of literature when discussing Salafism. The bulk of which does not apply to their religious beliefs. The discussion of the jihadists' religious beliefs has stagnated somewhat. As the quietists dictate the religious foundation, and the political Salafis look to peaceful implementation, the jihadists stand out primarily for their actions and less for their religion.

\section{Rhetoric}

The discussion of the Salafist's politics largely ignores the role of the quietists. The apparent reason is due to the quietists' adamant desires to remain beyond

23 Wiktorowicz, Quintan. "Anatomy of the Salafi Movement." Studies in Conflict \& Terrorism 29, no. 3 (2006): 207-39. https://doi.org/10.1080/10576100500497004. 208.

24 Jones, Seth G. A persistent threat: The evolution of Al Qa'ida and other Salafi jihadists. Santa Monica CA: RAND, 2014. 02-03.

25 Lenz-Raymann, Kathrin. Securitization of Islam: A vicious circle counter-terrorism and freedom of religion in Central Asia. Global, local Islam. Bielefeld: Transcript, 2014. https://www.jstor.org/stable/j. ctv1fxg.jp. 70-71.

26 Reese, Scott S. "Salafi Transformations: Aden and the changing voice of religious reform int he interwar Indian Ocean.” International Journal of Middle Eastern Studies 44, no. 1 (2012): 71-92. https:// doi.org/10.1017/S0020743811001255. 73-74.

27 Osman, Mohamed N. M. "Salafi Ulama in UMNO: Political Convergence or Expediency?" Contemporary Southeast Asia 36, no. 2 (2014): 206. https://doi.org/10.1355/cs36-2b. 224-225. 
the political process and solely dictate the religious elements of Salafism..$^{28}$ The less apparent reason is the fundamental disagreement the political and jihadists branches have with the quietists about their role in promoting Islamism..$^{29}$ The quietist ulama seek a different set of goals than their political and extremist brethren, which comes out in the lack of discussion about their political stance or interpretation of events. ${ }^{30}$ These discussions primarily regard the political means the Salafis use to gain peaceful traction in the various governments, and how they distance themselves from jihadists of the same name. Beyond their pragmatic successes, the literature defends the Salafis' actions in politics in contrary to that of the quietists and the jihadists. ${ }^{31}$ The common form of research questions at this level is how the political Salafist reconciles the peace-seeking and jihad-seeking rhetoric of their religion to implement a form of Islamism that a popular majority could support. ${ }^{32}$ These sources commonly involve a discourse between Salafi or Muslim scholars and non-Mus- lim authors generating an image of what the political Salafist seeks in its final form. The jihadists look to contemporary interpretations of the Salaf to justify long-term lesser jihads. ${ }^{33}$ The bulk of the literature regarding the jihadists' rhetoric is made up of attempts to both dissuade other Muslims from joining the movement and demonstrate to the non-Muslims that the umma (global Muslim community) does not follow the jihadists' ways. In academic discussions, this has created a body of works that look at the rationalized differences between Salafi jihadists and the rest of Islam. ${ }^{34}$ Internal discussions seek to discredit the contemporary interpretations of the Salaf by both discrediting the interpreters and establishing the contextual nature of pro-jihadist rhetoric. ${ }^{35}$ This area of literature is lacking substantial academic analysis of areligious variables, such as the psychological value of leadership to religious cultures.

\section{Actions}

The dominating elements of this corner of the literature focuses on the Salafi

28 Kose (2017b), 16-18.

29 Teplesky, Jacob M. "Salafi-Jihadism: A 1,400-Year-old Idea Rises Again.” Monograph, School of Advanced Military Studies, United States Army Command and General Staff College, 2016. 11-15.

30 Duderija, Adis. "The Salafi Worldview and the Hermeneutical Limits of Mainstream Sunni Critique of Salafi-Jihadism." Studies in Conflict \& Terrorism (2018): 1-16. https://doi.org/10.1080/105761 0X.2018.1529359. 03.

31 Malik, Maszlee, and Hamidah Mat. “The Historical Development of the "Sunnah" Reform Ideology in the State of Perlis, Malaysia." SAGE Open 7, no. 3 (2017): 1-12. https://doi.org/10.1177/21582 44017726356. 01-02.

32 Wiktorowicz, 214-216.

33 Kose (2017b), 17-18.

34 Maher, 08-12.

35 Bin Ali, Mohamed. The roots of religious extremism: Understanding the Salafi Doctrine of Al-Wala' wal Bara.' London: Imperial College Press, 2016. Kindle. 66-70. 
jihadists. Where the quietists and political Salafis do attract attention, it is frequently in comparison to jihadist groups, like Al Qaeda or the Islamic State. ${ }^{36}$ The politics and rhetoric of the three subsects stand out in distinction as the limiting qualities between and among each other. The branches are organized enough to denote that once a Muslim, scholar or lay, commits to another's course of action they are recognized and associated with that new rhetoric. The literature has evolved much in line with this practical manner of association. No matter what branch the individual claims to associate with, the literature spends time organizing the stated doctrine of that individual into its appropriate classification. This is likely where the distinction of the scientific Salafism emerges. ${ }^{37}$ With so many Muslims claiming an intentional Salafist following, the literature has committed parts of its discussion to creating hermeneutical limits between these codified beliefs. ${ }^{38}$ In general, the academic literature regards the Salafi jihadists almost as a form of apostasy to whatever the authors are comparing their beliefs against. From the Muslim authors' perspectives, this is likely to separate the beliefs of the majority of the umma from these particularly violent extremists. The non-Muslim au- thors' perspectives analyze the Salafi jihadists through the lens of answering why they are violent and how they became that way. There is very little discussion that looks beyond the development of cultural extremism through religious methods.

\section{Theoretical Framework}

$\mathrm{s}$ it is defined for this study, ra-
tionalism is the process of dis-
tilling the vague and obscure into the realistic and the describable. ${ }^{39}$ Rationalism is not the theoretical framework used for many of the sources cited in this review, but it is present in many of the findings and results. The very nature of applying shari'a and fiqh demands a limited application of rationalism. ${ }^{40}$ Otherwise, concepts like ijtihad and bid'a could not rest against the bulwark of taqlid. Additionally, and as a product of the limited availability of primary sources, rationalism is used to explain the subjects' logical conclusions about their religion and their roles. In this study rationalism provided the translative element for corporeal logic to theological. Rationalism contributes to diluting extraneous information and assists in focusing the research on a limited pool of variables that can be organized and explained within context. ${ }^{41}$

36 Jones, 01-03.

37 Bin Ali, 221-223.

38 Duderija (2018), 09-13.

39 Robertson, J. M. Rationalism. London: Constable and Company LTD, 1912. 13-14.

40 Nelson, Alan J. A companion to rationalism. Blackwell companions to philosophy 8. Oxford: Blackwell, 2005. 26-27.

41 Ibid., 30. 


\section{Summary}

The review of the literature observed patterns across the four subjects of study through the examination of the Muslim versus non-Muslim authors, the comparison of extremists versus moderates, and extremists versus other extremists. The patterns rarely exist independently of each other, and often rely on the materials of their opposites for academic support. This internal dependence is indicative of a further trend within the literature that was not established at the beginning of this review, but is addressed in this research's question. There is little general comparison between the moderate Deobandis and Salafis and their extremist subsects, the Taliban and Salafi jihadists. There are significant gaps within the literature reviewed, with a vein of apologists running through many of the popular sources. There are areas of the literature, such as the subjects' philosophical doctrine, which are not commonly available in academic discussion. Instead of providing the primary sources and discussions around their topics, the literature looks to what scholars, both religious and academic, have ruled on the matter. This is likely a characteristic of how the personal versus the academic perspectives of ijtihad and taqlid are treated by the four subjects.

\section{METHODOLOGY}

7 he literature review exhibits a well-developed field of studies around the four subjects. This field is predominantly qualitative, and seeks to explain the translations between the theoretical and ritual elements of Islam and its faultier practical emulations. Much of this literature exists within an academic sphere of discussion and debate, it does not typically address comparison. The existing body is still heavily concerned with translation, as opposed to internal comparison. The purpose of this study is to initiate part of that comparison between two general moderate sects and a couple of their extremist offspring. The research question is answered by following a meta-ethnographic approach aided by reciprocal translation as the chosen method of meta-synthesis. ${ }^{42}$ This approach specifically looks to address the comparative elements that define the sects and subsects as unique beliefs within Islam, but not unique from each other.

\section{Research Design}

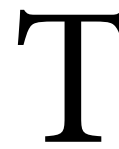
his research followed a two-part methodology. The first part, meta-ethnography, is a form of meta-synthesis that uses ethnographic accounts and qualitative studies as comparative values against each other. ${ }^{43}$ Meta-synthesis is already a practice that

42 Noblit, George, and R. Hare, eds. Meta-Ethnography. California: SAGE Publications, Inc, 1988. https://doi.org/10.4135/9781412985000. 13-15.

43 Ibid., 28. 
seeks to explain the "why" and "how" between studies, meta-ethnographies seek to use a more limited pool of qualitative information for comparison. ${ }^{44}$ The appropriate result of this approach illuminates the shared characteristics between the subjects of study as it relates to the focus of their study. The second part of this method involves the translating process of qualitative elements. The basic explanation of this translation is explained through comparative means. The practice of translation seeks to maintain the core concept of comparison between the subjects in relation to the key concepts within the account's setting. ${ }^{45}$ It takes the concepts from one account and compares them to concepts in a different account. In the case of this research's focus, the four primary subjects served as the themes of comparison, while their outstanding theoretical, ritual, and practical elements stand out as concepts of comparison.

\section{Limitations}

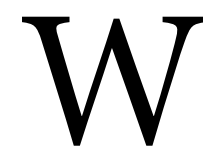
hile this methodology provides a flow and guidance to the development of a research project through comparative translation, synthesis, and analysis, its assumptions limit its general usage across a wider spectrum. There is rarely a defined minimal limit to the sources a study relies upon to make its case. The study is the distillation of thought from the combined sources and the conclusions that the researchers derived. In this case, the body of knowledge was built from several dozen sources of variety, but, prior to the research, did not exist. Where a concept was raised in one subject, a correlative was sought in the others for comparison. This practice effectively removed the limitation of a fledgling body of knowledge, while fostering growth and understanding towards the study's goals.

\section{Summary}

his two-part methodology led
the research through a step-
by-step process of comparative analysis between the broad subjects of study to highlight the shared elements within the subtleties of their doctrine and practice. As it pertains to this study's purpose, the methodology is specifically designed to compare theoretical, ritual, and practical concepts between the four subjects. The method not only serves to compare, but also realizes which concepts may not be universal to the four subjects, but are limited to a few. The other benefit of this organization is that it is methodical in practice as well as theory.

\section{FINDINGS \& ANALYSIS}

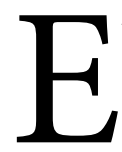
ven within a narrowed scope of comparing Deobandi and Salafi moderates and extremists, the

44 Mohammed, Mohammed A., Rebekah J. Moles, and Timothy F. Chen. "Meta-Synthesis of Qualitative Research: the Challenges and Opportunities." International journal of clinical pharmacy 38, no. 3 (2016): 695-704. https://doi.org/10.1007/s11096-016-0289-2. 697.

45 Ibid., 30-39. 
cone of relevant information was wide. The key task of this research revolved around sifting through this cone for recurrent ideologies that applied to the four primary subjects, while attempting to limit the singularity of these practices to only these four subjects. This goal contrasts with simply highlighting qualities that are practiced across greater Islam, or even just Sunnism. The following section is organized into two primary elements, Deobandism and Salafism, within in a scale ascending political extremism. Each section highlights unique developments and interpretations the subsects' practitioners have made to suit their interpretation of how and why sharia and fiqh should be applied. As these are fully established sects and subsects there are many concepts and practices that are not addressed in this study. The concepts and practices included were identified based on the terms of the study, and selected for their similarity to each other across the different subjects of focus.

\section{Deobandism}

$\mathrm{T}$ The Dar-Ulum-Deoband was founded out of the pronounced need to restore quality and control to academic Islam within the Indian subcontinent during its period within the English Empire. ${ }^{46}$ As such, their curriculum is based in promoting the manqulat (revealed sciences) over the rational sciences (maqulat). ${ }^{47}$ The Deobandi madrasas take the Muslim traditions to the original sources and focuses their curriculum on holy writs, preferring to teach from the $\mathrm{Qu}$ ran and Hadiths, instead of incorporating the centuries of discursive Islam. ${ }^{48}$ This fundamentalist's approach to their education originally served to separate the Deobandis from the numerous other and longer-standing madrasas in the subcontinent. Initially, fatwas were issued in direct opposition to competing madaras, like Barelwi, which were more tolerant of the mesh of Indian-Islamic cultures. ${ }^{49}$ This was presumably done to both demonstrate how far their competition had strayed from the true Islam, and to recruit a larger base of local Muslims. ${ }^{50}$ The initial years of fatwas were broad strokes, eliminating cultural practices tied to sufism (mystic traditions), shirk (polytheism), and bid'a. This either removed the influence of the more liberal madrasa or, at the very least, challenged their legitimacy through the comparison of practices.

Deobandism loosely follows the tradition established by Shah Waliullah, which fundamentally emphasizes the balance of shari'a with tariqah (Sufi

46 Ingram (2018), 2309-2323.

$47 \mathrm{Moj}, 31$.

48 Ibid., 16.

49 Ibid., 08.

50 Ingram, Brannon. "Sufis, Scholars and Scapegoats: Rashīd A囚mad Gangohī (d. 1905) and the Deobandi Critique of Sufism." The Muslim World 99, no. 3 (2009): 478-501. https://doi.org/10.1111/ j.1478-1913.2009.01281.x. 481-482. 
tradition of a spiritual journey to seek an ultimate truth).$^{51}$ In terms of sharia, Deobandism diverged from al-Waliullah's attempt at immediately raising the educational standard of all Muslims through tatbiq (the process of rationalizing two conflicting ideas). ${ }^{52}$ This was a process of al-Waliullah's design and sought to increase the legitimacy of ijtihad from the Hanafi figh. In this way, the ulama could practice ijtihad through a carefully controlled and restricted academic process, while still disseminating a conservative, anti-Sufi, anti-Shi'a Islam to their congregations. Due to a history of violent conflict and ideological attrition, however, Deobandism eventually abandoned the al-Waliullah tradition in favor of strict adherence to the Hanafi figh. ${ }^{53}$. Hanafism, as distributed by the Deobandi, is strict enough for the lay Muslim to live within its boundaries without abundant fear of shirk or kufr (sin, corruption), and, more importantly, simple enough for the lay Muslim to apply it in their routine lives while also being vague enough to create a reliance on the Deobandi ulama..$^{54}$ The Hanafi's brand of fiqh is well-designed to create a separation between the congregation and the ulama, as it is loose enough to allow the ulama to issue fatwas on culturally specific issues without contradicting the core shari'a. ${ }^{55}$

The Deobandi's initial organization of the curriculum at their central university promoted a franchisee structure and culture to Deobandism as a manner of learning and practicing Islam. ${ }^{56}$ In a relatively short amount of time, they cornered the market on academically defining the proper and improper Muslim lifestyles. Over time the nature of the fatwas changed from defensively restoring the normative Islam from its Hindu influences, to offensively implementing certain elements of sharia which could be practiced without an Islamic state..$^{57}$ At this point, Deobandism is heavily characterized through pronouncement of Shi'a as shirk, controlling the quality of the ula$m a$, and the political promotion of an Islamist government..$^{58}$

51 Edgar, Iain R. The dream in Islam: From Quranic tradition to Jihadist inspiration. New York, NY: Berghahn Books, 2011. 91.

52 Shahid, Amir K. "Displacement of Shah Waliullah's Movement and its Impact on Northern Indian Muslim Revivalist Thoughts." Journal of the Research Society of Pakistan 51, no. 2 (2014). 06.

53 Moj, 33-42.

54 White, 03.

55 Hamid, Myra. "The political struggles of the ulama of Dar-ul-Uloom Deoband: Identifying and operaitonalizing the traditionalist approach to politics." Master's Thesis, University of Maryland, College Park, 2005. 32.

56 Zaman, 2395.

57 Moj, 32.

58 Ibid., 17. 


\section{Deobandi Taliban}

I n contrast to the Deobandi ulama in Dar-Ulum-Deoband, the Deobandi Taliban began as students attempting to restore peace and Islamism to Afghanistan, in the post-Soviet environment. ${ }^{59}$ They began as refugee talibs (students) graduating from the Haqqaniya madrasa in Pakistan. The Deobandi Dar-Ulum-Haqqaniya, as led by Mawlana Sami' al-Haqq, used its prime location to prepare students for the world within the terms of jihad. The connection to the ulama is crucial, not only for spiritual guidance, but also provided legitimacy to their leadership, despite their incomplete understanding of sharia, when they were hastily thrust from the Haqqaniya. ${ }^{60}$ The Taliban's incomplete education, from top to bottom, ties them to the fundamentals, which can be taught and indoctrinated in a short amount of time. ${ }^{61}$ Concepts like al-amr bi'l-ma'ruf wa'l-nahy 'an al-munkar (commanding what is right and forbidding what is wrong) are necessary to motivate refugees to return to their despoiled lands for their benefit. ${ }^{62}$
The Afghan Taliban entered the scene in 1994 during the Afghan civil war. ${ }^{63}$ For the most part, including much of the leadership, the Taliban were unmolded students of the Deobandi madrasas on the Pakistani northwestern borders. ${ }^{64}$ Once released, they were guided by men like Mullah Omar: the products of an errant curriculum not controlled by a centrally-defined ulama, a multi-generational war of international interference, the tribal culture of Pashtunwali, and exposure to exceedingly successful Saudi Wahhabis working in Afghanistan's conflicts. ${ }^{65}$ The resulting shari'a was based in extreme fundamentalism that, although not expressly stated by the sources, incorporated al-Wahhab's perspective on ittaba'a (literal application of holy writs), and did so without the guidance of an experienced ulama. Without the guiding ulama, or even a central document like a constitution (beyond the Quran and Hanafi fiqh), the Taliban followed the exemplified purity of their leadership and their Prophet. ${ }^{66}$ Indeed, they prosecuted Afghanistan through jihad to unite under their brand of Islam, but not through academic dis-

59 Zaman, 2189.

60 Zaman, 2230.

61 Rashid, Ahmed. Taliban: Militant Islam, oil and fundamentalism in Central Asia. 2nd ed. New Haven CT: Yale University Press, 2010. 23.

62 Mahendrarajah, Shivan. "Saudi Arabia, Wahhabism, and the Taliban of Afghanistan: 'Puritanical reform' as a 'revolutionary war' program.” Small Wars \& Insurgencies 26, no. 3 (2015): 383-407. https:// doi.org/10.1080/09592318.2014.982883. 384.

63 Rashid, 20.

64 Ibid., 89-90.

65 Syed, Jawad, Edwina Pio, Tahir Kamran, and Abbas Zaidi. Faith-based violence and Deobandi militancy in Pakistan. London: Palgrave Macmillan, 2016. 2173.; Zaman, 2239; Rashid, 04, 89-90.

66 Rashid, 93. 
cipline like Deobandism. This is, in part, the explanation for behaviors like the Shi'a purges in Hazarajat, and the doctrinally unsupported fatwas issued against women's roles in society. ${ }^{67}$

At first glance the Pakistani Taliban follows the same line of fundamentalism as the Afghan Taliban. They are made up of hastily graduated talib from the Deobandi madrasas on, or near the Afghan border's with Pakistan. They follow the Hanafi Sunni tradition for their fiqh, and interpret the Islamic holy writs through an unacknowledged ittaba'a. ${ }^{68}$ Much of the Pakistani Taliban's population is comprised of deserters or retreating members of the Afghan Taliban, of which were likely trained in the Pakistani Deobandi madrasa, in any case. ${ }^{69}$ The similarities are evidenced by their social structure and by their victims. ${ }^{70}$ Additionally, their scholastic and political connections to the Jamaat-e-Islam (JI) and the Jamiat Ulema-e-Islam (JUI) through the madrasas are much stronger than in the remote deserts of Afghanistan. The JUI's (commonly) and JI's (less common) sectarian discourse is prone to both waver and adjust the Pakistani Taliban's political and martial intentions as their strength waxes and wanes in the Pakistani political spheres. ${ }^{71}$

\section{Salafi Quietists}

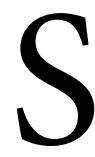

alafi quietists are strictly concerned with the maintenance and careful propagation of the Salaf's Islam. ${ }^{72}$ They follow the core belief that the manhaj (method) of Islam from the al-salaf al-salihin must retain its identity and purity from its time and circumstances from history. From the fundamentalist's perspective of the Salafists, as put forth by ulama, such as ibn Taymiyyah and Mohammad Abd al-Wahhab, Islam is the divine religion, requiring no adaptation to fit the circumstantial requirements of mankind. ${ }^{73}$ The Salafist's ijtihad is the corrective attempt, with significant restrictions, against temporal entropy to both maintain legitimacy in the present and adhere to the standards of practice from the past. ${ }^{74}$ The ijtihad is supposed to be the solution to that application, but there are some inconsistencies within the ulama with regards to the role and relationships of ijtihad and taqlid. Generally associated with the Sunni madhabs, the Salafi taqlid is not universally accepted, nor

67 Ibid., 72-75, 107.

68 Moj, 106-107.

69 Rashid, 25-26, 93.

70 Fair, C. C. "Explaining Support for Sectarian Terrorism in Pakistan: Piety, Maslak and Sharia." Religions 6, no. 4 (2015): 1137-67. https://doi.org/10.3390/rel6041137. 1141-1142, 1151.

71 Rashid, 92; Moj, 103-107.

72 Wagemakers, Joas, ed. Oxford Research Encyclopedia of Religion. Oxford University Press, 2016. 12.

73 al-Wahhab, Al-Imam M. I. Explanation of the Nullifiers of Islam, 2016. 06; ibn Talmiyyah, Al-Islam. Enjoining Right and Forbidding Wrong. 03-06.

74 Bin Ali, 67. 
condemned, but serves its purpose as a conduit for the present to interpret the past. ${ }^{75}$ This is accomplished with two different application of the taqlid. There is the stagnant taqlid, which is concrete and is taught as rhetoric for educating lay Muslims and new scholars. This is the taqlid al-amaa, (blind following), and it requires no input or interpretation from its adherents, only stipulating that it is taught in its entirety. ${ }^{76}$ The other, is a dynamic taqlid, and fills the role of answering the questions of the contemporary Salafi jurists, as they operate beyond the fiqh and influence of any one madhab. ${ }^{77}$

The talfiq (piecing together) and ikhtilaf (differences of opinion) are characteristics that reinforce the credibility of the ulama's ruling, or at least are responsible for mitigating any accidental bid'a. The talfiq serves to give the Mujtahid (scholars qualified to rule on matters of ijtihad) restrictive guidance in the compilation of his juristic response, and is reminiscent of other scholarly research processes. ${ }^{78}$ The $i k h t i-$ laf continues the scholarly tone through the emphasis of the religious version of "peer review," and serves as the opposite to concurrence, ijma (legal consensus). ${ }^{79}$ The ikhtilaf serves to ensure that singular member of an ulama becomes too enamored with their methodology and analysis production. If an ulama is agreed upon in certain matters, such as Bin Baz in the case of ruling on Western troops in Saudi Arabia, they may issue rulings that effectively updates sharia's logical applications. ${ }^{80}$ It is critical to note that the sharia itself is not being changed, but how it is applied is the subject of debate and change. Further, those of the ulama who issue incorrectly, but within the terms of the holy writ, may not be subject to takfir (excommunication), especially if the ruling was made with a misinterpretation of the language or historical context. ${ }^{81}$ Within the vein of takfir, as was alluded to in the review of the literature, the Salafi quietists do not associate with, nor pronounce takfir against the Salafi ihadists. ${ }^{82}$

The quietist's goal is to prevent the further fraction and descent into extremism (from the Salafist's view) for the rest of Islam. In this, the quietists

75 Krawietz, Birgit. “Cut and Paste in Legal Rules: Designing Islamic Norms with Talfiq." Die Welt des Islams 42, no. 1 (2002): 3-40. http://www.jstor.com/stable/1571293. 09.

76 Fareed, Muneer. “Against Ijtihad.” The Muslim World 91, 3, 4 (2001): 355-70. 356.

77 Fariha, Fatima, and Pakeeza Shahzadi. "Ijtihad as a Legislative Function: Role of Ijtihad, Ifta and Taqleed in Legislative Process." Journal of Islamic and Religious Studies 1, no. 1 (2016): 33-45. https:// doi.org/10.12816/0032208. 40-42.

78 Krawietz, 07-09.

79 Aljloud, Saad A. "Ijtihād and Ikhtilāf: Re-interpreting Islamic Principles in Contemporary Times." Arab Law Quarterly 28, no. 1 (2014): 85-98. https://doi.org/10.1163/15730255-12341273. 92-93.

80 Maher, 130-133.

81 al-Wahhab, 10.

82 Maher, 98. 
are adherent practitioners of irja (to defer or postpone), and consider the unity of ideals and peoples within the umma to be significantly more important than routing out minor takfirs or bid'a within the community. ${ }^{83}$ This is where certain restrictions of interpretive methodology come into play that distinguish the quietists from the rest of Salafism. One such restricted methodology is the mafhum al-muwafaqa, the process of reaching a logical conclusion based on concepts not explicitly stated in the Quran. ${ }^{84}$

\section{Salafi Jihadists}

7 he Salafi jihadists, while making up the smallest population of one of the smallest sects within
Sunnism and the general umma, with little doubt, have attracted the greatest attention for their capabilities to implement ideology and rhetoric into extremist practices. ${ }^{85}$ Despite this attention, it is difficult to define the Salafi jihadists in ideological terms. If their manhaj of interpreting and applying the Quran and Hadiths was forced into a mold, the mold would appear derivative of the Salafi quietist scholars. Much like derivatives, the Salafi jihadists are logically removed by several steps from the quietists' absolutism. They reject the madhabs, bid'a, and any measure of innovation that would remove or marginalize the divinity of Allah in the texts. ${ }^{86}$ The al-salaf al-sälihin exhibited the premier Muslim ideals, governance, and culture. As such, the fundamentals are about where the jihadists break from normative Salafism and implement their version of ijtihad.

The jihadist's ijtihad takes advantage of an absent ulama, which permits those Mujtahid to develop their rhetoric without the significant limitations of ikhtilaf. The ijma is significantly more pronounced in the jihadists, as there are fewer scholars who are qualified to speak on definitive measures, issues fatwas, and lead congregations. ${ }^{87}$ This is not to state that the ijtihad is without boundary, or that jihadists operate without concern of being the targeted by takfir through bid'a (although al-Wahhab states that the scholars are above takfir if they come to an incorrect conclusion because of mistranslation, misunderstanding, or misrepresentation). ${ }^{88}$ The boundaries of normative Salafi ijtihad run perpendicular to itta$b a^{\prime} a$. Ittaba'a, in synchrony with al-Wahhab's lowered standard for entry into Islamic scholarship, permits the literalist's interpretation of the holy writs. ${ }^{89}$

83 Maher, 78-79; Zaman, 2497.

84 Maher, 50.

85 Syed, et al., 262.

86 Malik and Mat, 01.

87 Fareed, 359.

88 al-Wahhab, 06-07.

89 Evazpour, Mehdi, and Hamdallah Akvani. "Fiqh for Action: Jihadi Salafists and Rethinking in Salafi Jurisprudential Foundations.” Politics and Religion 8, no. 1 (2019): 55-77. 61-62. 
The absent academic discipline and ikhtilaf from the jihadist scholars who apply ittaba'a permits an ijtihad that does not carry any weight to influence normative Islamic thought, and simultaneously provides answers to other lay Muslims who are equally uneducated, but are motivated to dedicate their lives to Islam..$^{90}$ All considered, the fount of logic within the jihadists is based in $i j$ tihad and al-Wahhab's insistence of the propagation of Islamic studies through relaxed disciplines and removal of restricted accesses. ${ }^{91}$

Once the foundation for academic deterioration is lain, the argument for offensive jihad must be made. This argument begins with hakimiyya. Hakimiyya is the act of protecting the rights of self-governance handed down from Allah. ${ }^{92}$ Some scholars, particularly Qutbists, argue that hakimiyya as the defensible behavior to preventing Islam from slipping back into Jahiliyya (polytheistic period before the Prophet's arrival). ${ }^{93}$ In terms of the jihadists, it is a call to action and commitment to jihad, to prevent that slip and restore a true caliphate under sharia. ${ }^{94}$ The logic of the hakimiyya is used as further evidence to prove the bleeding situation of contemporary Islam. The absence of a true Islamic state, yet the quantity of Muslim-led governments provides material evidence of either the weakness of Islam, because of external oppression or the weakness of the Muslims leading the governments, who should be more focused on Islamism than secular issues. ${ }^{95}$

These rhetorical foundations are inextricably tied to their ideologies and follow a continuous rationale from one to the other. It begins with the case of defensive versus offensive jihad. The offensive jihad is only declared by a righteous authority, like the Caliph, and is solely for the purpose of territorial or political expansion..$^{96}$ Under the terms, and the absence of a formal caliphate, there is no clear rationalized path to declare an offensive jihad from an outlaw organization. Further, it is reasoned by some, such as Muhammed Nasir al-Din Albani, that a Caliph is less likely to arise without the proper realization of 'aqida (maintenance of doctrinal purity) through al-tasfìya wa-l-tarbiya (education and purification). The rhetoric and rationale of defensive jihad, however, is much easier to substantiate and execute. Defensive jihad is a conflict borne out of the necessity to defend the

90 Ibid., 63.

91 al-Wahhab, 06-07.

92 al-Mawardi, 区Ali i. M., and Wafaa H. Wahba. Al-Ahkam Al-Sultaniyya: The Laws of Islamic Governance. Great Books of Islamic Civilization. Reading: Garnet, 1996. 10.

93 Qutb, Sayyid. Milestones. 14th ed. New Delhi: Islamic Book Service, 2002. 07.

94 Azzam, Abdullah. Defense of the Muslim Lands: The First Obligation After Iman. At-Tibyan Publications. 13-15, 34-35.

95 Mimouni, Abdelghani. "Debating al-Hakimiyyah and Takfir in Salafism: The Genesis of Intra-Salafi Schism in the 1990s." Doctoral, University of Exeter, 2016. 72-73.

96 Maher, 35. 
umma from destruction due to external influences, typically political. ${ }^{97}$ The defensive jihad must be carried out for two reasons. The first stipulates that to wait for an impossibility, such as complete Islamic reform or the return of the caliphate to carry out the jihad would be equivalent of removing the concept from the religion altogether. The second is within the fiqh al-muwāzanāt (the jurisprudence of balances), or in this case, choosing the lesser of two evils. ${ }^{98}$

Stepping further along the path of rationalized jihadism, al-wala' wa-lbara' (loyalty and disavowal) draws the line between the pious and the non-believer. ${ }^{99}$ As a defensive concept aligned with protecting Islam from polytheists (shirk), nonbelievers ( $k u f r)$, and revisionists (bid'a) it determines those who are worthy of exposure to the secrets of Islam. ${ }^{100}$ In jihadism, al-wala' wa-l-bara' create a "national" identity for the Islamic umma. Those who are within that scope are welcomed and given the um$m a$ 's resources, while those who are beyond the scope, or even threaten those within, are subject to jihad. ${ }^{101}$ Further, the threat from beyond, with the scope of al-wala' wa-l-bara' is a task for Muslims to both distinguish themselves in their faith show their capability to defend Islam from kufr. ${ }^{102}$ If al-wala' wa-lbara' protected Islam from the $k u f r$ and enemy without Islam, then takfir protects Islam from the $k u f r$ and the enemy within Islam.

\section{Analysis}

\section{Considerations for Deobandism and Quietist Salafism}

In the terms of their sharia, both of these scholastically-oriented sects are "scripturalists," meaning their foundational studies are based solely on the Quran and Hadiths, rather than including the centuries of commentary and development of Islamic jurisprudence and philosophical discussions. ${ }^{103}$ Both groups also look to ijtihad as a tool of rationalism to both answer questions regarding contemporary problems, and to translate the context of the past into the present. The Deobandis look at ijtihad within the restrictions of the Hanafi fiqh, which provides substantial delineators to guide the rationale. ${ }^{104}$ These limitations, in addition to the taqlid, creates a restricted, yet reasonable conclusion-reaching paradigm for the Deobandi ulama. By comparison, the

97 Moyeed-ul-Zafar. "Contribution of Shaykh Nasir al Din Albani to Hadith Literature." Doctoral Dissertation, Department of Islamic Studies, Aligarh Muslim University, 2005. 276-277.

98 Azzam (n.d.), 14-20.

99 Bhatt, Chetan. “The Virtues of Violence: The Salafi-Jihadi Political Universe.” Theory, Culture \& Society 31, no. 1 (2014): 25-48. https://doi.org/10.1177/0263276413500079. 32-33.

100 Wagemakers, 11.

101 Bin Ali, 71-73.

102 Ibid., 77-79.

103 Moj, 16; Evazpour and Akvani, 61-62.

104 Moj, 33-42. 
Salafi quietists rely more heavily on the taqlid to provide the decision-making paradigm within ijtihad. ${ }^{105}$ Without the madhab to provide a fiqh, there are less restrictions in interpretation. This supposed philosophical freedom is countered by the talfiq and ikhtilaf, which are supposed to prevent any bid'a. Both groups prohibit bid'a, but do not provide exacting legal tests or practices that would indicate when an interpretative conclusion becomes bid'a or remains ijtihad. This absentee definition is partially responsible for the splintering and evolution of their subsequent subsects.

The ulama's role in both sects has significantly determined how far the shari'a can evolve to the contemporary circumstances. The Salafi ulama, particularly the Wahhabis, command strict control over their publications, edicts, fatwas, etc., and perform ikhtilaf within the tenured positions of the ulama. ${ }^{106}$ This control does much to ensure the unity of the "proper" Salafi tradition, but does little to address the Khawarij's ("those who have gone out") heresy. ${ }^{107}$ The Deobandi ulama follow a similar behavior, where they are ultimately concerned with the quality and integrity of their curriculum within the Hanafi madhab, but have very little recourse in the way of pronouncing takfir upon their graduates who commit to an illegal jihad, or even maintain madrasas with the intent of providing its graduates as mujahidin (soldiers of a jihad). ${ }^{108}$ This lack of control of subsects and political movements within the sect may be attributable to the lack of a centralized and linear command structure. Without the Caliphate and singular leader, as ordained by Allah, who can appropriately apply the correct sharia, there will always be a competition to both devise the best sharia or to prove the ideal sharia through application.

\section{Considerations for Deobandi \\ Taliban and Salafi Jihadists}

Both Deobandi Taliban and Salafi jihadists develop their sharia beyond the traditional guidelines and restrictions of their normative brethren. The Deobandis adhere to the Hanafi fiqh, but the Taliban have yet to develop documentation on their anticipated sharia. ${ }^{109}$ They practice ittaba'a on the holy writs, as it regards governance of societies, in conjunction with the Pashtunwali, where it concerns a civil and criminal solution. In continuance of the absentee fiqh, the Salafi jihadists are presently more concerned with executing their global jihad, than they are with developing a practical shari'a within a geographical space (the Islamic State led by al-Baghdadi being the exception). As these groups prosecute the national or global jihads, they have rationalized the role of jihad as a fundamental part

105 Bin Ali, 67.

106 Aljloud, 92-93.

107 Bin Ali, 233-234.

108 Zaman, 2189.

109 Rashid, 105. 
of Islam. The "struggle" is necessary to sustain Islam with pure, loyal, and good Muslims. However, neither group has addressed the solution to the absentee jihad if their missions are successful. If jihad is a necessary and fundamental aspect of Islam, and if Islamism were to master the world, then Islam either must not be the true religion or it must turn on itself to achieve higher levels of idealism. This eventuality within their terms of success yields another trend throughout both groups', particularly the Salafi jihadists' ideologies, which indicates evolving dichotomies that are reminiscent of Manichaeism. ${ }^{110}$ Concepts like al-walä' wa-l-barā', haqq wa batil (truth and deceit), and iman wa $k u f r$ (faith and disbelief) are cornerstones in rationalizing violence against others, and, more importantly, against other Muslims. These qualities, once postulated, are applied to sort the jihadists from the rest of the world, from the rest of Islam, and, ultimately, from the rest of their humanity. From these dualities, the jihadists are separated from their victims through a clearly defined and rationalized path.

When the world is divided in binary terms it is easy to discern who is the enemy, who is the non-combatant, and who is the fellow mujahidin. ${ }^{111}$ Without a normative ulama to reign control over the jihadists, there is no limit to their ijtihad. Noting this, it is important to return to the notion that neither normative Salafis or Deobandis provide a limiting test for bid'a. There is certainly the concept and definition of bid'a, but within the terms of an absolute legal test, there is no agreed upon method to secure a standard. ${ }^{112}$ The absence of the definition has allowed jihadist leaders like Bin Laden, al-Zarqawi, Mullah Omar, Haqqani, etc. to distill ijtihad through ittaba'a. The result appears as bid'a to the layman, but is rationalized within academic rationalization practices like mafhum al-muwafaqa or mafhum al-mukhalafa ("the understanding of the opposite"). ${ }^{113}$ The result is generations of poorly trained Islamic students following moderately-to-well trained leaders, though hardly scholars, towards a rationalized goal of global sharia, but without an operational shari'a to implement once that opportunity is upon them.

\section{Summary}

There is a habit of comparing Deobandism and quietist Salafism, particularly Wahhabism, regarding their approach of shari'a with mentions of fiqh. ${ }^{114}$ There are some similarities in fundamental backgrounds. Both ulamas retain strict control over their sects' doctrine and proliferation, both ensure a separation between educated classes and

110 Bonino, Stefano. "Violent and Non-Violent Political Islam in a Global Context." Political Studies Review 16, no. 1 (2018): 46-59. https://doi.org/10.1177/1478929916675123. 53.

111 Bin Ali, 110-112.

112 Kose (2017a), 04.

113 Maher, 46, 49-50.

114 Moj, 17. 
the lay Muslim, and both design themselves around implementing shari'a. Beyond that, there are few similarities in their practices. Where Salafism rose to prominence through shared mutual politico-religious authority with the Sau'd family, the Deobandis fought, sometimes literally, for their political prominence, a power that commonly wanes more than waxes. ${ }^{115}$ This initial start into the political arena further separated the two sects in how they continued to pursue sharia. The Salafis maintain a relationship with the Arabian royalty and leadership for a balance of politics and religious acquiescence. This has allowed the quietist Salafist ulama to maintain a strict control over their brand of Salafism and support an Islamist agenda. The Deobandis rely on a two-fold supportive framework that started with the commitment to the Hanafi taqlid and was distributed through their vast network of madrasas. Instead of being able to dictate the terms of Islamism from the top-down, the Deobandis commonly find themselves at odds with a political agenda of securing an Islamic state while also permitting a degree of tolerance for non-Deobandi Muslims. ${ }^{116}$ This struggle has added to the degree of theological drift the Deobandi sharia has undergone. The jihadist subsects of both scholastic disciplines are frequently aligned in their rationale. They use vague or restricted method- ologies within ijtihad, taqlid, and fiqh (Deobandis through Hanafism) to reach prearranged conclusion to justify the purpose and opponents of the jihad. This is opposed to the methodologies of the normative ulama which use the Quran, Hadiths, and madhab to come to an unknown conclusion, then test that conclusion against the merits of other arguments. In terms of sharia and the jihadists in this study, they have yet to demonstrate an interest in normalizing and codifying an operational sharia that can be applied to a peaceful Islamic state. The Taliban came the closest with their occupation of Kabul, but this system was temporary and sought to aid the mujahidin on the front lines before attempting to return the city to a functional society. ${ }^{117}$

These points have answered the research question and highlighted where the general limits of the sharia and fiqh of the Deobandis and Salafis intersect. All four subjects covered in this study seek to promote their particular brand of sharia. These groups use a combination of the Quran and Hadiths to support their arguments. For the most part, these are the only unifying documents amongst the subjects, and they tend to splinter after this point. The Deobandis apply the Hanafi fiqh to support the political aspects of their sharia with moderate long-term successes. In contrast, the Salafis disregard

115 Khushboo. “The politics of Madrassa Education in Pakistan: Nexus with Militancy." International Journal of Social Science 8, no. 2 (2019): 51-61. https://doi.org/10.30954/2249-6637.02.2019.3. 5557.; Maher, 114.

116 Zaman, 1395.

117 Rashid, 50, 105-106. 
the notion of fiqh and the madhabs as bid'a, and work within the strictures of non-madhab specific taqlid and ijtihad to address political and evolutionary concerns as Islam comes across obstacles beyond the experiences of the Salaf. The ulamas of the Deobandi and Salafi seek to ensure the security of the taqlid before looking beyond at other goals within Islam. The jihadists use the holy writs to support their arguments as a foregone conclusion. Instead of altering their theories to suit the reality, they change the reality to suit their theories. This is an important note, as their moderate sects use holy materials like the Quran and Hadiths to evolve and develop theological treatises, the jihadists use the holy materials in piecemeal to support pre-existing arguments. This is how they can reconcile the targeting of Muslims, and other forbidden groups. They view the world in binary terms, without much tolerance for grey areas. The absence of a universal definition and test for bid'a is largely responsible for these rationalizations, as both jihadist groups (Taliban and Salafi jihadists) abstain and forbid bid'a, and yet some interpretation has taken place. From the broad scope of this study there are no clear characteristics shared by the four primary subjects that are not shared by other sects within Islam. A common theme amongst all subjects reviewed in this study is the dread that stagnancy of the 'aqida will lead Islam to return to the periods of Jahiliyya. Although this is not a concept that is solely applicable to these subjects, much less this religion. The historical connection to the Prophet and His immediate followers lends significant legitimacy to the clergy and their arguments, regardless of the nature of these arguments. In general, though, this is a typical Sunni characteristic, as established by the logic behind their creation. They follow the lineage of logic as an aid to pursue the contemporary logic. Where they splinter, is determined by their pre-determined goals, and their manhaj.

\section{CONCLUSIONS AND RECOMMENDATIONS FOR ADDITIONAL RESEARCH}

his research study compara-
tively addressed the similarities
in the extremist ideologies and practices of the Deobandi Taliban and Salafi jihadists, versus their moderate origins in Deobandism and normative Salafism. This comparison was applied in the research so that their commonalities could be distilled and highlighted for further study, and used as insight into the evolution of politico-religious extremism. The research was solely qualitative and used a two-part meta-synthesis methodology with a focus on meta-ethnography to incorporate the primary accounts and cultural contexts within the range of acceptable sources. The methodology was chosen to address why and how the subjects distilled the uncompromising tenets of their religion to suit their desires for law and warfare. The research question was answered through this manner, as it was limited solely to those qualities that spanned across the philosophical, practical, Deobandi's, and Salafi's development and practice of shari'a and figh. 


\section{Conclusions}

The study's findings revealed an additional circumstance that was not considered upon its design, which are the effects of chronic war and military conflict on the development of legal treatise as dictated through a religion. The observation that a missing centralized religious authority is desired from the four subjects is neither unique to this research, nor does it go unnoticed by the practitioners. Sunni Islam suffers from its requirements to maintain doctrinal integrity, but lacks the universally righteous authorities to intervene when conflict in doctrine arises. Part of this conflict comes from an absence of universal consideration towards the religion's fundamentals. This serves as a partial explanation for why incredibly important concepts like bid'a go without a unifying legal test. To provide a test to all Sunnis would not only secure the superiority of the initiative sect, but would also jeopardize the corporeal and spiritual standings of all other sects and subsects, who would find themselves in opposition to the universal authority.

Elements of the hypothesis were refuted by this research, there were no ideologies that are shared amongst the four primary subjects of focus that are solely unique to these four within the terms of greater Islam. There were elements of the subjects' doctrines that were outlined and compared beyond the terms of their individual circumstances. Instead of proving the subjects were unique within these terms, the similar elements within the doctrines revealed common traits of rationale and logic. This conclusion was reached within the hypothesis by comparing how the different subjects restricted and permitted their behaviors based on logical conclusions they reached within the doctrine. One recurring theme within this research is the subjects' dedication to their logical doctrinal findings. None of their doctrinal conclusions were reached without rationalizing the elements of the doctrine to specifically fit their global ideologies. Within the hypothesis, this means that the routes of rationale need to be highlighted for further study. If these subjects are coming to similar conclusions, through wildly different origins and circumstances, then there are further similarities amongst these subjects.

\section{Recommendations for Additional Research}

The broad scope of this research
study means that there are many
avenues that future research may take. The first recommendation for future research in comparing these four subjects is to examine the ijtihad of the four subjects through the restrictions of their definitions of bid'a. The absence of a unified legal test for bid'a permits a great deal of leeway for individuals to incorrectly rationalize sharia. An interesting direction for future research would examine the similarities in their bid'a and attempt to explain the fundamental causes in their differences of practice. Another recommendation for this research is to re-examine these subjects within the scope of their polit- 
ical psychology. These groups' political psychology goes beyond the demands of religion and simply states what behaviors and creeds are acceptable to the population of followers. This angle of research should reveal additional similarities within the four subjects beyond their political and religious inclinations. The final recommendation is to perform leadership personality assessments for the four founding leaders with specific emphasis on their cognitive analyses. As their followers have tried to emulate the ideal behaviors of Mullah Omar, the Salaf, Maududi, ibn Taymiyyah, etc., they have tried to carry their mentalities and logic forward into the future as well. These cognitive analyses may be used in comparison against one another to distinguish additional similarities in their sects' lines of logic.

Joshua Pease holds an MA in Intelligence Analysis and a MPS in Homeland Security Studies. His primary area of research includes the application of historical events in comparison against contemporary intelligence analysis questions. Highlights from his research include identifying the shared qualities across seemingly irreconcilable Sunni, Muslim subsects. He welcomes opportunities for continued research and collaboration.

James Hess holds a Ph.D. from Louisiana State University. He is professor of intelligence and terrorism studies at American Military University's School of Security and Global Studies. His research interests are Islamic jurisprudence, terrorism, and improving analytical processes for intelligence analysis. 